Deiksis: Jurnal Pendidikan Bahasa dan Sastra Indonesia, 7 (1) Januari 2020

DOI: 10.33603/deiksis.v7i1.2219

(p-ISSN 2355-6633, e-ISSN 2548-5490)

\title{
Toponimi Desa-Desa di Kecamatan Ciawigebang, Kabupaten Kuningan
}

\author{
Yani Septiani $^{1)}$, Itaristanti ${ }^{2}$, Indrya Mulyaningsih ${ }^{3)}$ \\ yaniseptiani096@gmail.com ${ }^{1)}$, itaristanti@yahoo.com ${ }^{2}$, indrya.m@gmail.com³) \\ 1) 2) 3)IAIN Syekh Nurjati, Cirebon
}

\begin{abstract}
Abstrak. Nama merupakan suatu hal yang sangat diperlukan sebagai identitas atau penanda. Nama atau penanda tidak hanya digunakan untuk nama seseorang, tetapi juga untuk nama suatu wilayah/ tempat. Penamaan suatu tempat merupakan bagian dari kajian toponimi atau asal-usul penamaan tempat. Zaman sekarang hanya sedikit masyarakat yang mengetahui asal muasal desa dan budaya yang terdapat di dalamnya. Oleh karena itu, adanya penelitian ini diharapkan masyarakat dapat menyadari pentingnya sebuah sejarah. Tujuan penelitian ini, yaitu untuk mendeskripsikan bentuk dan makna, serta faktor yang memengaruhi penamaan desa yang berada di Kecamatan Ciawigebang, Kabupaten Kuningan. Metode yang digunakan dalam penelitian ini, yaitu metode wawancara. Selanjutnya menggunakan teknik cakap semuka, teknik pancing, teknik rekam dan teknik catat, kemudian dianalisis dan dideskripsikan. Kecamatan Ciawigebang, Kabupaten Kuningan memiliki 24 desa. Hasil penelitian menunjukkan bahwa dalam penamaan desa di Kecamatan Ciawigebang merupakan bentuk komposisi/ gabungan dari dua sampai tiga kata. Selain itu, dalam penamaan desa juga menggunakan afiksasi atau penambahan imbuhan, seperti Desa Pamijahan, Karangkamulyan, dan Kapandayan. penamaan desa itu memiliki makna yang berhubungan dengan pimpinan, harapan masyarakat setempat, kebiasaan penduduk, letak, keadaan lingkungan hidup yang dikeramatkan, dan sejarah yang ada di desa setempat. aktor yang memengaruhi penamaan desa-desa di Kecamatan Ciawigebang, Kabupaten Kuningan, yaitu faktor sosial, lingkungan hidup, sejarah, letak dan geografis.
\end{abstract}

Kata kunci: toponimi, asal-usul, desa, penamaan

\section{Pendahuluan}

Menurut Odssey (dalam Istiana, 2012), nama merupakan salah satu bagian terpenting untuk seseorang atau sesuatu. Tidak seorang pun, baik dari yang terendah maupun yang tinggi derajatnya, yang hidup tanpa nama begitu memasuki (lahir) dunia. Hal tersebut menunjukkan bahwa sebuah nama itu sangat diperlukan sebagai identitas atau penanda. Kemudian nama atau penanda tersebut tidak hanya digunakan untuk nama seseorang, tetapi juga untuk nama suatu wilayah atau tempat.

Adanya penamaan suatu tempat dapat memberikan tanda pengenal. Bahkan, pembeda antara satu tempat dengan tempat yang lain. Kemudian dengan adanya toponimi, suatu wilayah dapat diketahui dan diakui keberadaannya. Toponimi tidak hanya berkaitan dengan kondisi fisik letak geografisnya, akan tetapi juga berhubungan dengan kebudayaan, perilaku masyarakat, serta agama yang dianut masyarakat tertentu (Istiana, 2012). Sebagai contoh, di Jawa Barat terdapat legenda Sangkuriang yang melatarbelakangi terbentuknya Gunung Tangkuban Perahu. Kemudian legenda Bandung Bondowoso dan Roro Jonggrang yang melatarbelakangi terbentuknya Candi Prambanan. Contoh tersebut menunjukkan bahwa terdapat penamaan tempat sebagai cerminan sosiokultural kehidupan sosial, ideologis, dan 
Deiksis: Jurnal Pendidikan Bahasa dan Sastra Indonesia, 7 (1) Januari 2020

DOI: 10.33603/deiksis.v7i1.2219

(p-ISSN 2355-6633, e-ISSN 2548-5490)

nilai-nilai yang dianut masyarakat. Hal tersebut menunjukkan bahwa tidak ada nama tempat yang tidak mempunyai arti (Ruspandi \& Mulyadi, 2014).

Penelitian ini bertujuan untuk mendeskripsikan bentuk dan makna yang terkandung dalam penamaan desa, serta faktor yang memengaruhi penamaan desa di Kecamatan Ciawigebang, Kabupaten Kuningan. Adanya penelitian terkait toponimi ini menjadi salah satu cara untuk menggali informasi mengenai cerita-cerita dan budaya yang berada di daerah atau desa. Pada masa otonom saat ini, telah terjadi kesenjangan terkait penulisan sejarah lokal. Hal tersebut dapat dilihat dari banyaknya orang yang hanya membicarakan permasalahan saat ini, tanpa melihat sejarah sehingga aspek historis dilupakan. Ilmu sejarah juga sebenarnya dapat dijadikan sebagai salah satu cara pemecahan masalah sesuai konteks masalah yang dihadapi. Dengan adanya sejarah, permasalahan terkait potensi suatu daerah pun dapat diselesaikan (Pianto, 2016).

Menurut KBBI V, kecamatan adalah daerah bagian kabupaten (kota) yang membawahi beberapa desa atau kelurahan, dikepalai oleh seorang camat. Menurut KBBI V, desa adalah kesatuan wilayah yang dihuni oleh sejumlah keluarga yang mempunyai sistem pemerintahan sendiri (dikepalai oleh seorang kepala desa). Kecamatan Ciawigebang adalah salah satu kecamatan yang berada di Kabupaten Kuningan. Kabupaten Kuningan memiliki 32 kecamatan, sedangkan kecamatan Ciawigebang memiliki 24 desa.

Zaman sekarang hanya sedikit masyarakat yang mengetahui asal muasal desa dan budaya yang terdapat di dalamnya. Penulisan sejarah tidak hanya menuliskan cerita orang besar atau cerita politik, tetapi juga untuk sejarah pedesaan. Selain itu, dengan adanya dokumentasi sejarah memungkinkan tumbuhnya rasa bangga terhadap desa sendiri. Kebanggan tersebut dapat memacu semangat dan tidak memandang bahwa daerah atau kota lain lebih menarik dari desanya sendiri (Romadi \& dkk, 2010).

Selain itu, asal-usul dari sebuah tempat juga merupakan cerita warisan yang harus dijaga. Menurut Purwanto (2010), tidak sedikit cerita rakyat yang berkembang di dalam suatu masyarakat. Akan tetapi, para generasi saat ini tidak mengetahui cerita tersebut serta orangorang yang mengetahui cerita tersebut sudah berkurang karena masyarakat atau orang yang mengetahuinya adalah orang yang sudah memiliki usia yang sudah tua. Dalam hal ini, para generasi penerus juga perlu adanya pengenalan budaya minimal dengan pengenalan cerita rakyat. Cerita rakyat atau folklor merupakan salah satu dari sastra lisan. Cerita rakyat adalah cerita yang diwariskan sejak zaman dahulu yang disampaikan secara lisan atau biasa dikenal cerita yang disampaikan dari mulut ke mulut (Sutriati, WS, \& Zulfadhli, 2012). Menurut Sukmana (2018), cerita rakyat juga merupakan bentuk tuturan yang dijadikan sebagai media ungkapan perilaku masyarakat mengenai nilai-nilai kehidupan yang sangat melekat dalam kehidupan masyarakat.

Kemudian folklor juga memiliki fungsi dalam dunia pendidikan. Folklor berfungsi sebagai media pendidikan. Folklor berguna sebagai alat atau penyampai informasi untuk menyampaikan budaya lokal setempat dan dapat digunakan sebagai pembelajaran untuk memahami berbagai aspek kehidupan (Endraswara, 2013). Menurut Komariah (2018), karya sastra juga dapat dijadikan sebagai salah satu media pendidikan karakter. Hal tersebut dikarenakan karya sastra memiliki bahasa yang kuat sehingga mampu menyentuh perasaan 
Deiksis: Jurnal Pendidikan Bahasa dan Sastra Indonesia, 7 (1) Januari 2020

DOI: 10.33603/deiksis.v7i1.2219

(p-ISSN 2355-6633, e-ISSN 2548-5490)

manusia. Selain itu, cerita rakyat juga dapat meningkatkan nilai-nilai karakter yang positif pada peserta didik. Dengan adanya usaha pengenalan cerita rakyat, budaya yang dimiliki oleh masyarakat Indonesia yang khas dan beragam akan terus berkembang di dalam masyarakat.

Hasil dari penelitian ini diperoleh dari melakukan observasi terhadap masyarakat. Dalam kaitannya, sudah diketahui bahwa bahasa dan masyarakat juga menjadi bagian yang tak terpisahkan dalam sebuah penamaan tempat. Kehidupan sosial atau kebiasaan masyarakat akan menjadi ciri khas antarwilayah.

Sosiolinguistik merupakan ilmu antardisiplin antara Sosiologi dan Linguistik. Ilmu sosiologi mengkaji atau meneliti masyarakat itu terjadi, berlangsung, dan tetap ada. Selain itu, sosiologi juga mempelajari segala yang berkaitan dengan permasalahan sosial dalam masyarakat sampai cara manusia menyesuaikan diri dengan lingkungan. Linguistik adalah bidang ilmu yang menjadikan bahasa sebagai objek kajiannya. Berdasarkan hal tersebut, sosiolinguistik merupakan antardisiplin ilmu yang mempelajari penggunaan bahasa dalam masyarakat (Chaer \& Agustina, 2014). Sosio adalah masyarakat dan linguistik adalah kajian bahasa. Jadi, sosiolinguistik itu mengkaji tentang bahasa yang dikaitkan dengan masyarakat (Sumarsono, 2017).

Menurut Koentjaraningrat (dalam Chaer \& Agustina, 2014), kebudayaan itu tumbuh dan berkembang dengan masyarakat dan milik manusia. Bahasa juga menjadi salah satu bagian dari kebudayaan. Bahasa merupakan unsur utama yang mengandung kebudayaan yang dimiliki oleh manusia. Menurut Masinambouw (dalam Chaer \& Agustina, 2014), bahasa dan kebudayaan adalah dua sistem yang berkaitan erat dengan manusia. Kebudayaan merupakan sistem yang mengatur interaksi antarmasyarakat dan bahasa sebagai suatu sistem sarana untuk berinteraksi. Banyak ahli yang menyatakan bahwa kebudayaan merupakan main system (sistem atasan) dan bahasa itu sebagai subsystem (sistem bawahan). Bahasa sangat dipengaruhi oleh budaya. Salah satu cerminan dari budaya adalah bahasa. Dengan demikian, tampak bahwa dengan bahasa seseorang atau masyarakat dapat diketahui kebudayaaan orang tersebut (Aslinda \& Syafyahya, 2014).

Penjabaran tersebut menunjukkan bahwa bahasa dan budaya sangat berkaitan. Ketika ingin menganalisis suatu budaya, terlebih dahulu harus mengetahui bahasa yang digunakan di tempat tersebut, begitu pun ketika ingin mengkaji bahasa pasti tak lepas dari pengaruh budaya. Budaya menjadi salah satu faktor yang memengaruhi bahasa yang digunakan di suatu wilayah.

Menurut KBBI V, toponimi adalah cabang onomastika yang menyelidiki nama tempat. Toponimi (dalam bahasa Inggris: toponymy) adalah salah satu bidang ilmu yang mempelajari toponimi serta totalitas dari toponim dalam suatu region. Ilmu Toponimi menyangkut hal yang mempelajari nama suatu tempat, tentunya sangat erat kaitannya dengan bidang keilmuan lain seperti sejarah, budaya dan bahasa. Seseorang yang ingin belajar toponimi sudah seharusnya juga mempelajari ketiga bidang ilmu tersebut (Asadi, 2015).

Berdasarkan pengertian di atas, dapat dipahami bahwa salah satu ilmu yang mengkaji mengenai penamaan suatu tempat adalah toponimi. Selain itu dalam kajian toponimi tidak hanya mengkaji secara makna leksikal saja, akan tetapi dari berbagai faktor yang memengaruhi penamaan tempat tersebut. Faktor tersebut di antaranya, faktor sosial dan budaya. Adanya kedua faktor tersebut membuat bahasa di berbagai tempat berbeda. 
Deiksis: Jurnal Pendidikan Bahasa dan Sastra Indonesia, 7 (1) Januari 2020

DOI: $10.33603 /$ deiksis.v7i1.2219

(p-ISSN 2355-6633, e-ISSN 2548-5490)

Piliang (dalam Camalia, 2015), menyatakan bahwa dalam konteks cultural studies, keberadaan tanda dan teks tidak dapat dilepaskan dari konteks sosial, sebagaimana tanda dan teks itu berada. Tanda dan teks hanya dapat berfungsi bila digunakan oleh komunitas atau masyarakatnya. Penggunaan sistem tanda ini merupakan suatu bentuk konvensi yang menghasilkan makna dan nilai-nilai sosial tertentu di dalam masyarakatnya. Berdasarkan hal tersebut, dalam proses penamaan suatu tempat tidak terlepas dari bahasa, budaya, dan pikiran. Toponimi tidak terlepas dari aspek kajian linguistik, geografi, sejarah, antropologi, dan kebudayaan (Camalia, 2015).

Seperti yang sudah dijelaskan, bahwa setiap penamaan tempat memiliki arti atau makna yang menyebabkan nama tersebut dicetuskan pada desa atau wilayah. Secara etimologi, kata semantik berasal dari bahasa Yunani semantickos yang berarti 'penting; berarti', yang diturunkan pula dari semainein 'memperlihatkan; menyatakan' yang berasal pula dari sema 'tanda' seperti yang terdapat dalam kata semaphore yang berarti 'tiang sinyal yang dipergunakan sebagai tanda oleh kereta api' (Tarigan, 2009). Semantik menurut Aminuddin (2016), semantik yang semula berasal dari bahasa Yunani, mengandung makna to signify atau memaknai. Dalam istilah teknis, semantik juga berarti "studi tentang makna". Dengan anggapan bahwa makna menjadi bagian dari bahasa, maka semantik merupakan bagian dari linguistik. Menurut Parera (2004), semantik merupakan salah satu studi dan pembahasan mengenai analisi makna dalam linguistik.

Bahasa tidak terlepas dari kode dan lambang serta makna. Menurut Saussure (dalam Aminuddin, 2016), bahasa memiliki tiga unsur, yaitu langue adalah bahasa yang digunakan secara umum, langgage adalah bahasa yang digunakan secara khusus yang akan membentuk kelompok atau register, dan parole adalah wujud bahasa tersebut.

Langue merupakan sistem bahasa yang berkaitan dengan budaya karena bahasa yang diperoleh berdasarkan anggota masyarakat tersebut. Sistem sapaan contohnya, hal tersebut sangat ditentukan oleh sistem hubungan pemeran, baik di dalam maupun di luar kelompok kekerabatan. Sistem kebahasaan sangat berperan dalam upaya memahami wujud kebahasaan atau signal yang direpresentasikan oleh pemakai (Aminuddin, 2016).

Dalam proses penamaan, semantik adalah salah satu ilmu yang mempelajari atau mengkaji makna sebuah nama. Diberikannya nama terhadap sesuatu pasti memiliki alasan tertentu. Penamaan juga berkaitan dengan lambang atau simbol terkait suatu konsep yang muncul ketika mendengar lambang yang didengar atau dibaca.

Setiap bahasa pasti memiliki makna. Makna tersebut dapat berupa makna leksikal, gramatikal, atau idiomatik. Dalam kaitannya dengan penamaan sebuah tempat, seperti yang telah dijelaskan bahwa penamaan sebuah tempat pasti memiliki asal-usul diberikannya nama kepada suatu tempat. Hal tersebut sangat berkaitan dengan makna. Pada proses penamaan terdapat sebab atau peristiwa yang melatarbelakangi penamaan suatu tempat, di antaranya peniruan bunyi, penyebutan bagian, penemu dan pembuat, penyebutan sifat khas, tempat asal, bahan, keserupaan, pemendekan, dan penamaan baru.

Kemudian ilmu morfologi digunakan untuk menganalisis mengenai bentuk nama desa yang berada di Kecamatan Ciawigebang. Data yang dihasilkan pada saat penelitian akan dikaji asal kata penamaan desa. Proses morfologi adalah pembentukan kata dari bentuk dasar melalui 
Deiksis: Jurnal Pendidikan Bahasa dan Sastra Indonesia, 7 (1) Januari 2020

DOI: $10.33603 /$ deiksis.v7i1.2219

(p-ISSN 2355-6633, e-ISSN 2548-5490) pembubuhan afiks, pengulangan, penggabungan, pemendekan, dan pengubahan status (Chaer, 2008). Morfologi adalah ilmu yang mempelajari mengenai seluk beluk kata dan morfem (Ramlan, 2005). Menurut KBBI V, morfologi adalah cabang linguistik tentang morfem dan kombinasinya atau ilmu bentuk kata. Secara etimologi, kata morfologi berasal dari kata morf yang berarti 'bentuk' dan kata logi yang berarti 'ilmu'. Secara harfiah, morfologi adalah ilmu mengenai bentuk (Chaer, 2008). Dengan adanya ilmu morfologi, dalam penelitian ini akan meneliti asal bentuk dasar dari nama-nama desa yang berada di Kecamatan Ciawigebang.

\section{Metode}

a. Pendekatan Penelitian

Pendekatan yang digunakan yaitu pendekatan kualitatif. Menurut Sugiyono (2014), pendekatan kualitatif sering disebut metode naturalistik karena penelitiannya dilakukan pada kondisi yang alamiah (natural setting); disebut juga metode etnograpi karena pada awalnya metode ini digunakan untuk penelitian antropologi budaya, selain itu disebut metode kualitatif karena data yang didapatkan dan analisisnya bersifat kualitatif. Objek penelitian pada metode ini yaitu objek yang berkembang apa adanya, tidak dimanipulasi oleh peneliti dan kehadiran peneliti tidak memengaruhi dinamika pada objek tersebut. Instrumen dalam penelitian ini yaitu orang atau human instrumen.

\section{b. Metode dan Instrumen Pengumpulan Data}

Metode Pengumpulan Data

Metode pengumpulan data yang digunakan, yaitu interviu/wawancara. Metode wawancara dilakukan dengan teknik cakap bertemu muka. Teknik rekam dan teknik catat adalah teknik lanjutan yang digunakan dalam metode wawancara (Mulyaningsih \& Itaristanti, 2018). Penelitian ini juga menggunakan teknik pancing. Dalam penelitian ini menggunakan tiga tahapan, yaitu mencari data, mengelola data, dan menyajikan data (Kurniasih \& Zuhriyah, 2017).

\section{c. Instrumen Pengumpulan Data}

Instrumen yang digunakan dalam penelitian ini, yaitu manusia (human instrument), tepatnya peneliti sendiri dengan pengetahuan dan kemampuan peneliti untuk menemukan data (Istiana, 2012). Alat yang digunakan, yaitu rekaman. Kemudian pada saat penelitian menggunakan daftar pertanyaan untuk melakukan wawancara dengan informan.

\section{d. Analisis Data}

Tahap analisis data ini dilakukan ketika data telah berhasil dikumpulkan. Analisis data ini menggambarkan proses yang akan dilalui pada saat penelitian. Metode yang digunakan dalam analisis data, yaitu metode padan. Data yang dihasilkan dari penelitian ini, yaitu data yang berasal dari bahasa Sunda. Metode padan adalah metode analisis data yang digunakan untuk memadankan suatu bahasa dengan sesuatu di luar bahasa. Salah satu alat penentu yang digunakan dalam metode padan adalah pengalih bahasaan. Perlunya alih bahasa, karena data bukan berupa bahasa Indonesia, akan tetapi bahasa Sunda. Contohnya, nama desa Ciawigebang 
Deiksis: Jurnal Pendidikan Bahasa dan Sastra Indonesia, 7 (1) Januari 2020

DOI: $10.33603 /$ deiksis.v7i1.2219

(p-ISSN 2355-6633, e-ISSN 2548-5490)

yang berasal dari kata ci/cai yang berarti 'air' dan awi yang berarti 'bambu', serta gebang merupakan nama pohon 'gebang"'. Nama desa tersebut berasal dari bahasa sunda dan perlu dialihbahasakan ke dalam bahasa Indonesia untuk memudahkan pembaca memahami tulisan. Berikut digambarkan alur proses analisis data.

\section{Hasil dan Pembahasan}

a. Hasil

Hasil penelitian ini akan disampaikan berdasarkan hasil wawancara di lapangan. Hasil tersebut berupa bentuk nama-nama desa di Kecamatan Ciawigebang, Kabupaten Kuningan. Kemudian disampaikan dalam pembentukan nama desa tersebut asal kata penamaan desa tersebut. Selanjutnya, yaitu makna dari nama-nama desa yang berada di Kecamatan Ciawigebang, Kabupaten Kuningan. Makna yang digunakan dalam deskripsi hasil penelitian ini merupakan gambaran makna yang dikenal atau diketahui oleh informan maupun masyarakat setempat.

a. Bentuk dan Makna Nama Desa yang Berada di Kecamatan Ciawigebang, Kabupaten Kuningan

Terdapat 24 desa yang berada di wilayah Kecamatan Ciawigebang, Kabupaten Kuningan. Kecamatan Ciawigebang ini merupakan wilayah terluas dan juga memiliki desa yang paling banyak di Kabupaten Kuningan.

Berikut bentuk nama desa-desa di Kecamatan Ciawigebang, Kabupaten Kuningan, yaitu 1) Desa Sukadana, 2) Desa Cihirup, 3) Desa Cikubangmulya, 4) Desa Cigarukgak, 5) Desa Pamijahan, 6) Karangkamulyan, 7) Desa Ciawilor, 8) Desa Pangkalan, 9) Desa Dukuhdalem, 10) Desa Ciomas, 11) Desa Cijagamulya, 12) Desa Kapandayan, 13) Desa Sidaraja, 14) Desa Pajawanlor, 15) Desa Ciputat, 16) Desa Lebaksiuh, 17) Desa Karamatmulya, 18) Desa Geresik, 19) Desa Kadurama, 20) Desa Ciawigebang, 21) Desa Cihaur, 22) Desa Mekarjaya, 23) Desa Padarama, dan 24) Desa Sukaraja.

Penamaan sebuah tempat memiliki ciri khasnya masing-masing. Setiap nama pasti memiliki makna atau arti. Biasanya arti atau makna dari nama tersebut berkaitan dengan sejarah terbentuknya desa tersebut. Dengan banyaknya budaya atau pun kebiasaan warga di suatu daerah, akhirnya setiap daerah memiliki makna yang unik dan beragam. Makna tersebut didapatkan berdasarkan penjelasan dari tokoh masyarakat setiap desa.

Makna yang terdapat dalam nama desa tersebut merupakan makna baru. Maksud dari makna baru tersebut karena dalam penamaan desa-desa tersebut terbentuk dari gabungan kata atau penambahan imbuhan. Dengan adanya proses morfologi tersebut dapat memberikan makna baru dari nama-nama desa tersebut. Berikut akan disajikan makna dari nama-nama desa yang berada di Kecamatan Ciawigebang.

Tabel 1. Makna Nama-Nama Desa di Kecamatan Ciawigebang, Kabupaten Kuningan

\begin{tabular}{cll}
\hline No. & \multicolumn{1}{c}{ Nama Desa } & \multicolumn{1}{c}{ Makna } \\
\hline 1 & Sukadana & dengan rasa suka pimpinan yang bernama Wedana \\
2 & Cihirup & mengizinkan atau mengesahkan menjadi desa \\
& & Air yang selalu mengalir (hirup)
\end{tabular}


Deiksis: Jurnal Pendidikan Bahasa dan Sastra Indonesia, 7 (1) Januari 2020

DOI: $10.33603 /$ deiksis.v7i1.2219

$\begin{array}{cll}3 & \text { Cikubangmulya } & \text { Kubangan air yang memberikan kehidupan } \\ 4 & \text { Cigarukgak } & \text { Air yang menggenangi jalan yang rusak } \\ 5 & \text { Pamijahan } & \text { Tempat perpindahan warga } \\ 6 & \text { Karangkamulyan } & \text { Sebuah lahan kosong yang menjadi tempat tinggal warga } \\ 7 & \text { Ciawilor } & \text { Desa yang terletak di sebelah utara kecamatan } \\ 8 & \text { Pangkalan } & \text { Tempat persinggahan/ berkumpulnya para wali } \\ 9 & \text { Dukuhdalem } & \text { Tempat persembunyian warga yang berada di dalam hutan } \\ 10 & \text { Ciomas } & \text { Air sumur yang berwarna emas } \\ 11 & \text { Cijagamulya } & \text { Sebuah harapan agar desa tersebut tetap terjaga dan tetap } \\ 12 & \text { Kapandayan } & \text { mulia } \\ 13 & \text { Sidaraja } & \text { Mayoritas warga desa setempat sebagai tukang pandai besi } \\ 14 & \text { Pajawanlor } & \text { Desa yang dipimpin oleh seorang pemimpin yang memiliki } \\ 15 & \text { Ciputat } & \text { tubuh yang kecil } \\ 16 & \text { Lebaksiuh } & \text { Sesa yang terletak di sebelah utara dari Desa Pajawan Kidul } \\ 17 & \text { Karamatmulya } & \text { Pohon Siuh yang berada di bawah dari desa lainnya } \\ 18 & \text { Geresik } & \text { Pohon yang dianggap kramat dan berharap desa itu tetap mulia } \\ 19 & \text { Kadurama } & \text { Warga desa yang kompak dan desa yang rapi } \\ & & \text { Pohon Kadu atau duren yang paling besar milik rama Eyang } \\ 20 & \text { Ciawigebang } & \text { Alimudin Bin Lukman } \\ & & \text { Sebuah Kademangan (Ciawi) yang ditaklukan oleh Pangeran } \\ 21 & \text { Cihaur } & \text { Sutajaya yang memiliki gelar Pangeran Gebang } \\ 22 & \text { Mekarjaya } & \text { Sumber mata air yang terus mengalir dan banyaknya pohon } \\ 23 & \text { Sukaraja } & \text { haur di sana } \\ & & \text { Sebuah harapan dari dimekarkannya desa agar tetap } \\ \text { bertumbuh kembang dan tetap berjaya }\end{array}$

b. Faktor yang memengaruhi penamaan Desa di Kecamatan Ciawigebang, Kabupaten Kuningan

Penamaan desa-desa yang berada di Kecamatan Ciawigebang, Kabupaten Kuningan juga tidak terlepas dari faktor yang melatarbelakangi terbentuknya atau diberikannya nama pada suatu tempat. Berikut tabel faktor yang memengaruhi penamaan desa yang berada di Kecamatan Ciawigebang, Kabupaten Kuningan.

Tabel 2. Faktor yang Memengaruhi Penamaan Desa-desa di Kecamatan Ciawigebang,

Kabupaten Kuningan

\begin{tabular}{|c|c|c|}
\hline No. & Faktor yang Memengaruhi & Desa \\
\hline 1. & Sosial & $\begin{array}{l}\text { Sukadana, Pamijahan, Cijagamulya, Kapandayan, } \\
\text { Geeresik, Mekarjaya, Padarama, dan Sukaraja }\end{array}$ \\
\hline 2. & Lingkungan Hidup & $\begin{array}{l}\text { Cihirup, Ciomas, Ciputat, Lebaksiuh, Kadurama, } \\
\text { dan Cihaur }\end{array}$ \\
\hline 3. & Sejarah atau Asal-usul & $\begin{array}{l}\text { Pangkalan, Sidaraja, } \quad \text { Pajawanlor, dan } \\
\text { Ciawigebang }\end{array}$ \\
\hline 4. & Letak & Ciawilor, Dukuhdalem, dan Karamatmulya \\
\hline 5. & Geografi & $\begin{array}{l}\text { Cikubangmulya, } \\
\text { Karangkamulyan }\end{array}$ \\
\hline
\end{tabular}

\section{Pembahasan}

Pada bagian ini, akan dibahas mengenai bentuk nama-nama desa, makna nama-nama desa, dan faktor yang memengaruhi penamaan desa yang berada di Kecamatan Ciawigebang. 
Deiksis: Jurnal Pendidikan Bahasa dan Sastra Indonesia, 7 (1) Januari 2020

DOI: 10.33603/deiksis.v7i1.2219

(p-ISSN 2355-6633, e-ISSN 2548-5490)

Pembahasan ini berdasarkan hasil penelitian yang telah dilakukan dan telah disampaikan di bagian sebelumnya.

a. Bentuk dan Makna yang Terkandung dalam Penamaan Desa di Kecamatan Ciawigebang, Kabupaten Kuningan

Pada bagian ini dibahas mengenai bentuk dan makna nama-nama desa, serta faktor yang memengaruhi penamaan desa yang berada di Kecamatan Ciawigebang, Kabupaten Kuningan.

\section{Desa Sukadanna}

Nama Desa Sukadana berasal dari dua kata, yaitu suka dan dana. Dalam data di atas, kata suka itu didasarkan bahwa dengan rasa suka dan rela warga Desa Cigarukgak memisahkan Kampung Bungbulang menjadi sebuah desa. Menurut KBBI V, 'suka' itu berarti 'senang' atau 'gemar' dan 'dana' itu diambil dari akhiran nama pemimpin yang bernama 'Wedana'.

\section{Desa Cihirup}

Nama Cihirup terbentuk karena desa tersebut memiliki sumber mata air yang tak pernah surut. Kata $c i$ di sana merupakan sebutan pendek dari cai. Menurut Sunandar (2018: 18), Cai berarti 'air'. Sesuai dengan kebiasaan bahwa di daerah setempat juga mengenal bahwa 'ci' itu bermakna 'air'. Kemudian kata hirup itu berarti 'hidup' (Sunandar, 2018: 35). Kata hidup di sana diartikan bahwa air yang berada dalam sumur tersebut selalu ada atau hidup dan konon katanya air tersebut suatu saat akan menjadi satu-satunya sumber mata air ketika musim kemarau yang sangat panjang.

\section{Desa Cikubangmulya}

Nama Cikubangmulya dibentuk dari tiga kata, yaitu ci yang berarti air (Sunandar, 2018: 18), kubang (Sunandar, 2018: 47) berarti 'kubangan', dan mulya atau mulia (KBBI V) yang berarti 'tinggi', 'luhur', dan 'bermutu tinggi'. Berdasarkan hal tersebut, dapat diketahui bahwa makna dari Cikubangmulya adalah sebuah kubangan air yang memiliki nilai tinggi karena dari kubangan tersebut dapat mengeluarkan air dan dapat menghidupi warga setempat, yaitu salah satunya mengairi tanaman palawija warga setempat.

\section{Desa Cigarukgak}

Kata Cigarukgak itu berasal dari dua kata, yaitu ci yang berarti 'air' (Sunandar, 2018: 18) dan garukgak yang diartikan sebagai 'rusak' atau 'berlubang'. Cigarukgak tersebut warga setempat mengenal dengan jalan yang rusak dan selalu digenangi oleh air ketika hujan karena tempat tersebut memiliki air yang banyak.

\section{Desa Pamijahan}

Nama Pamijahan ini diambil dari kata mijen kemudian diambillah kata 'mijah' untuk penamaan desa tersebut. Nama Pamijahan terbentuk dari $p a$ - yang merupakan awalan, mijah 
Deiksis: Jurnal Pendidikan Bahasa dan Sastra Indonesia, 7 (1) Januari 2020

DOI: 10.33603/deiksis.v7i1.2219

(p-ISSN 2355-6633, e-ISSN 2548-5490)

(Sunandar, 2018: 59) yang berarti 'bergerak terus' dan -an merupakan akhiran. Berdasarkan pemaknaan kata tersebut dapat diketahui bahwa makna dari kata pamijahan berarti berpindah atau bergerak atau perpindahan. Makna tersebut berkaitan dengan asal-usul nama tersebut, yaitu karena pada masa penjajahan tempat yang sekarang menjadi Desa Pamijahan merupakan tempat perpindahan warga Desa Ciawigebang untuk sembunyi dari musuhnya.

\section{Desa Karangkamulyan}

Penamaan desa ini sesuai dengan keadaan tempat saat itu. Penamaan Desa Karangkamulyan terdiri dari dua kata, yaitu karang yang berasal dari kata pekarangan (Sunandar, 2018, p. 43) yang berarti 'halaman' dan kamulyan yang diartikan sebagai 'kemuliaan'. Kedua makna tersebut diartikan sebagai halaman yang memiliki nilai luhur karena bermanfaat sebagai tempat tinggal warga.

\section{Desa Ciawilor}

Pemberian nama desa ini sesuai dengan bahasa Jawa. Kemudian desa ini juga merupakan desa yang dipisahkan dari Desa Ciawigebang. Ciawilor terdiri dari dua kata, yaitu ciawi yang diambil dari awalan desa induk dan lor yang diartikan sebagai kaler atau dalam KBBI V bahasa Jawa bermakna 'utara'. Berdasarkan kedua makna tersebut, dapat diketahui pula bahwa makna dari kata ciawilor adalah sebuah wilayah ciawi yang berada di sebelah utara Ciawigebang.

\section{Desa Pangkalan}

Selanjutnya Desa Pangkalan. Nama pangkalan terdiri atas satu kata, pangkalan dalam (KBBI V) berarti tempat yang dapat dijadikan sebagai 'tumpuan untuk menyerang musuh'. Dengan demikian, dapat disimpulkan bahwa pangkalan itu merupakan tempat yang dijadikan tumpuan. Namun dalam makna Desa Pangkalan diartikan sebagai tempat berkumpulnya para wali ketika hendak bepergian untuk menyebarkan ilmu agama.

\section{Desa Dukuhdalem}

Desa selanjutnya, yaitu desa yang dibentuk dari pamekaran Desa Pangkalan. Desa ini mulanya merupakan desa yang berada di dalam hutan. Nama Dukuhdalem terdiri dari dua kata, yaitu dukuh (Sunandar, 2018: 24) yang berarti 'duku' atau 'dusun' dan dalem atau dalam (KBBI V) 'rumah atau istana'. Berdasarkan pemaknaan tersebut, berarti dukuhdalem merupakan dusun yang berada di rumah atau istana. Namun, jika sesuai dengan asal-usul Desa Dukuh dalem diartikan sebagai tempat yang berada di dalam. Data di atas kata lain dari dukuh adalah pedukuhan yang merupakan dulunya tempat latihan silat yang dipimpin oleh Mbah Toyyibudin.

\section{Desa Ciomas}

Desa ini merupakan desa yang terletak di sebelah barat kecamatan. Nama ciomas terdiri atas dua kata, yaitu $c i$ (Sunandar, 2018: 18) yang berarti 'air' dan omas itu berasal dari emas atau mas yang diartikan atau diambil arti warna seperti emas. Berdasarkan kedua makna tersebut dapat diketahui bahwa ciomas berarti air yang berwarna seperti emas. Hal tersebut terjadi karena dari sebuah sumur yang mengeluarkan air yang berwarna emas. 


\section{Desa Cijagamulya}

Berikutnya adalah sebuah desa yang terletak di sebelah barat Desa Ciomas dan merupakan pamekaran dari desa tersebut. Cijagamulya dibentuk dari kata ci atau cai (Sunandar, 2018: 18) yang berarti 'air' dan diambil dari awalan desa induk, yaitu Desa Ciomas, jaga (KBBI V) yang berarti 'terjaga' atau 'bertugas menjaga keselamatan dan keamanan', dan mulya atau mulia (KBBI V) yang berarti 'tinggi', 'luhur', dan 'bermutu tinggi'. Dengan demikian, dapat disimpulkan bahwa makan dari cijagamulya desa yang terjaga dan bermutu tinggi.

\section{Desa Kapandayan}

Makna dari nama kapandayan diambil dari keahlian warga dalam membuat alat-alat rumah tangga. Nama kapandayan dibentuk dari ka- sebagai awalan, pandai (KBBI V) yang berarti 'mahir', 'cakap', dan atau 'terampil', dan - an sebagai akhiran. Dengan demikian, kapandaian dapat diartikan dengan kemahiran. Kemahiran tersebut merupakan alasan diberikannya nama kapandayan terhadap desa tersebut.

\section{Desa Sidaraja}

Desa yang terletak bertetangga dengan Desa Kapandayan ini merupakan desa induk dari Desa Kapandayan. Desa ini merupakan desa yang sampai saat ini belum diketahui tahun berdirinya. Desa sidaraja berasal dari kata sida yang diartikan sebagai 'kecil' atau 'anak kecil' dan raja yang diartikan sebagai 'pemimpin'. Dengan demikian, dapat disimpulkan bahwa sidaraja bermakna anak kecil yang memimpin atau wilayah yang dipimpin oleh anak kecil.

\section{Desa Pajawanlor}

Selanjutnya adalah desa yang mengalami dua kali pemisahan, pertama dipisahkan dari Desa Pajawan dan kedua dari Desa Ciputat. Pajawanlor itu dibentuk dari kata pajawan yang diartikan dengan sejarah, yaitu banyaknya pendatang dari jawa dan dijadikan panggilan kepada pendatang tersebut dan lor atau kaler yang berarti 'utara'. Dengan demikian, dapat disimpulkan bahwa makna pajawanlor merupakan sebuah daerah yang berada di sebelah utara dan pada masanya ditempati oleh orang jawa.

\section{Desa Ciputat}

Desa yang dimekarkan menjadi dua ini merupakan desa yang terletak sebelah selatan Desa Ciawigebang. Nama ciputat itu terdiri atas $c i$ atau cai yang diambil dari desa induk Desa Ciawigebang dan putat adalah sebuah nama pohon yang dianggap gaib oleh warga setempat. Dengan demikian, dapat disimpulkan bahwa ciputat itu bermakna sebuah tempat yang memiliki pohon keramat atau gaib.

\section{Desa Lebaksiuh}

Desa ini merupakan desa yang dalam penamaannya diambil dari keunikan sebuah pohon. Desa lebaksiuh itu terdiri atas dua kata, yaitu lebak (Sunandar, 2018, p. 49) yang berarti 
Deiksis: Jurnal Pendidikan Bahasa dan Sastra Indonesia, 7 (1) Januari 2020

DOI: $10.33603 /$ deiksis.v7i1.2219

(p-ISSN 2355-6633, e-ISSN 2548-5490)

'lembah' dan siuh merupakan nama pohon. Dengan demikian, dapat disimpulkan bahwa lebaksiuh merupakan pohon siuh yang berada di lembah. Pohon siuh tersebut memiliki kelebihan, yaitu ketika ditebang itu mengeluarkan air.

\section{Desa Karamatmulya}

Berikutnya adalah Desa Karamatmulya. Desa pamekaran dari Desa Geresik. Karamatmulya itu berasal dari dua kata karamat atau keramat (KBBI V) berarti 'sebuah tempat suci dan bertuah yang memiliki atau memberikan efek magis dan psikologis kepada pihak lain' dan mulya atau mulia yang berarti 'tinggi', 'luhur', dan 'bermutu tinggi'. Dengan demikian, dapat disimpulkan bahwa karamatmulya adalah sebuah tempat suci yang memiliki nilai magis dan memiliki nilai luhur. Kata keramat itu diambil dari sebuah makam yang dikeramatkan oleh warga setempat.

\section{Desa Geresik}

Desa yang terkenal dengan bersih dan kompak ini merupakan alasan diberikannya nama Geresik pada desa tersebut. Nama geresik terdiri atas ger yang berarti 'bergema atau serempak dan kompak' dan resik (Sunandar, 2018: 80) yang berarti 'bersih'. Dengan demikian, dapat disimpulkan bahwa geresik adalah sebuah desa yang bersih dan warga yang kompak. Makna tersebut sampai sekarang masih ditanamkan dalam warga setempat karena desa tersebut terlihat rapi dan bersih. Penggambaran keadaan sosial warga desa dicerminkan pada nama desa. Dengan demikian, diharapkan untuk seterusnya desa tersebut selalu kompak dan bersih.

\section{Desa Kadurama}

Desa ini merupakan desa pamekaran dari Desa Ciawigebang. Pada saat pamekarannya terjadi pertarungan antartokoh yang akhirnya dimenangkan oleh tokoh dari Kadurama. Tokoh tersebut menjadi salah satu alasan diberikannya nama kadurama pada desa tersebut. makna dari dua kata karena kadurama terdiri atas dua kata, yaitu kadu (Sunandar, 2018: 41) yang berarti 'durian' dan rama (Sunandar, 2018: 77) yang berarti 'ayah atau bahasa halus dari bapa'. Dengan demikian, dapat disimpulkan bahwa makna dari kadurama adalah sebuah durian milik bapa atau rama Eyang. Eyang Alimudin bin Lukman tersebut merupakan pemilik dari pohon durian dan konon katanya pohon durian itu pohon yang paling besar di antara pohon lainnya. Namun saat ini di Desa Kadurama tidak memiliki pohon durian sebanyak dulu.

\section{Desa Ciawigebang}

Desa selanjutnya adalah desa yang diperkirakan ada sejak zaman penjajahan dan kerajaan. Nama desa ini juga diambil dari salah satu tokoh yang menaklukkan wilayah yang sekarang menjadi Desa Ciawigebang. Ciawigebang dibentuk dari dua kata, yaitu ciawi yang merupakan kademangan atau (KBBI V) merupakan kepala distrik atau wedana pada zaman pemerintahan Hindia Belanda. Kemudian gebang diambil dari gelar Pangeran Sutajaya Gebang. Dengan demikian, dapat disimpulkan bahwa ciawigebang adalah daerah bekas penjajahan Hindia Belanda yang ditaklukan oleh Pangeran Gebang. Namun, informan juga mengatakan bahwa diperkirakan diberikannya nama ciawi pada wilayah tersebut karena pada 
Deiksis: Jurnal Pendidikan Bahasa dan Sastra Indonesia, 7 (1) Januari 2020

DOI: $10.33603 /$ deiksis.v7i1.2219

(p-ISSN 2355-6633, e-ISSN 2548-5490)

saat itu daerah tersebut memiliki sumber mata air yang melimpah dan dikelilingi oleh pohon bambu. Kata $c i$ dalam (Sunandar, 2018: 18) berarti 'air' dan awi dalam kamus Sunda-Indonesia berarti 'bambu'.

\section{Desa Cihaur}

Nama cihaur itu terdiri atas dua kata, yaitu $c i$ atau cai (Sunandar, 2018: 18) yang berarti 'air' dan haur merupakan nama pohon bambu. Dengan demikian, dapat disimpulkan bahwa cihaur merupakan air yang memiliki kelebihan yaitu dapat menyembuhkan penyakit dan sumber mata air yang dikelilingi oleh pohon bambu haur.

\section{Desa Mekarjaya}

Mekarjaya adalah sebuah desa yang terletak di sbelah utara dan desa pamekaran dari Desa Cihaur. Nama mekarjaya dibentuk dari dua kata, yaitu mekar (Sunandar, 2018: 57) yang berarti 'mekar' dan dalam (KBBI V) berarti 'menjadi bertambah luas'. Kemudian jaya (KBBI V) bermakna 'selalu berhasil atau sukses, dan atau heba't. Dengan demikian dapat disimpulkan bahwa nama mekarjaya berarti sebuah desa yang berharap selalu mekar dan berhasil. Harapan tersebut dijadikan sebuah motivasi dalam segala aspek kehidupan warga desa.

\section{Desa Padarama}

Desa ini merupakan desa yang terletak di bawah dan memiliki jalan yang cukup memperihatinkan. Jalan yang harus dilalui ketika ingin mendatangi desa tersebut cukup curam dan meskipun sering ada perbaikan tapi cepat rusak. Hal tersebut dikarenakan keadaan tanah yang rentan terbawa oleh air sehingga jalanan rentan berlubang. Padaram itu terdiri atas dua kata, yaitu pada (KBBI V) yang berarti 'menurut' dan rama (Sunandar, 2018: 77) yang berarti 'ayah atau bahasa halus dari bapa'. Dengan demikian, dapat disimpulkan bahwa makna dari padarama adalah nurut atau manut kepada bapa atau ayah. Maksud dari bapa atau ayah itu adalah pimpinan di desa tersebut.

\section{Desa Sukaraja}

Selanjutnya adalah desa yang pada masanya terkenal dengan hasil kebunya, yaitu Desa sukaraja. Desa ini memiliki makna yang berasal dari kehidupan sosial warga setempat. Sukaraja terdiri atas dua kata, yaitu suka (KBBI V) yang berarti 'girang hati' atau 'senang hati' dan raja (KBBI V) yang berarti 'sebutan untuk orang yang memiliki kekuasaan besar dalam suatu lingkungan'. Dengan demikian, dapat disimpulkan bahwa sukaraja itu berarti warga yang disenangi oleh pimpinan atau Bupati. Sampai saat ini, warga Desa Sukaraja terkenal dengan loyalitasnya. Misalnya, ketika ada acara warga selalu mengadakan acara yang meriah.

b. Faktor yang Memengaruhi Penamaan Desa di Kecamatan Ciawigebang, Kabupaten Kuningan 
Deiksis: Jurnal Pendidikan Bahasa dan Sastra Indonesia, 7 (1) Januari 2020

DOI: $10.33603 /$ deiksis.v7i1.2219

(p-ISSN 2355-6633, e-ISSN 2548-5490)

Dalam setiap penamaan suatu tempat, biasanya memiliki faktor yang melatarbelakangi terbentuknya nama suatu tempat. Berikut disajikan berdasarkan faktor yang memengaruhi penamaan desa-desa di Kecamatan Ciawigebang, Kabupaten Kuningan.

\section{Faktor Sosial}

Faktor sosial ini muncul karena dalam penamaan desa-desa di Kecamatan Ciawigebang, Kabupaten Kuningan berkaitan dengan masyarakat. Faktor yang melatarbangi penamaan tersebut diambil dari asal-usul penamaan desa. Adapun penamaan desa-desa yang dipengaruhi oleh faktor sosial sebagai berikut.

Desa Sukadana

Desa Pamijahan

Desa Cijagamulya

Desa Kapandayan

Desa Geresik

Desa Mekarjaya

Desa Padarama

Desa Sukaraja

Faktor yang memengaruhi penamaan Desa Sukadana adalah faktor sosial. Hal tersebut ditunjukkan dengan warga setempat memiliki nilai sosial yang tinggi karena dengan rela memberikan kebebasan kepada warga Kampung Bungbulang untuk memisahkan diri dari Desa Cigarukgak.

Faktor yang memengaruhi penamaan Desa Pamijahan itu karena adanya perpindahan. Oleh sebab itulah nama yang dulunya Kampung Pamijen diubah menjadi Desa Pamijahan. Faktor sosial tersebutlah yang memengaruhi penamaan desa tersebut.

Faktor yang memengaruhi penamaan Desa Cijagamulya, yaitu faktor sosial. Faktor tersebut didasarkan pada makna cijagamulya.

Faktor yang memengaruhi penamaan Desa Kapandayan, yaitu faktor sosial. Faktor tersebut didasarkan pada asal-usul penamaan desa tersebut. Nama kapandayan diambil dari kebiasaan atau keahlian warga yang bekerja sebagai tukang besi atau tukang pandai besi.

Faktor yang memengaruhi penamaan Desa Geresik, yaitu faktor sosial. Kehidupan warga desa yang kompak dan bersih menjadi alasan diberikannya nama geresik pada desa tersebut.

Faktor yang memengaruhi penamaan Desa Mekarjaya, yaitu faktor sosial. Faktor tersebut karena nama tersebut berasal dari harapan warga setempat yang menginginkan desa tersebut selalu berkembang dan memiliki nilai luhur yang baik. Selain itu, desa ini dapat dikatakan desa yang masih muda karena desa tersebut pamekaran dari Desa Cihaur dan dibentuk pada tahun 1980.

Faktor yang memengaruhi penamaan Desa Padarama, yaitu faktor sosial. Hal tersebut sesuai dengan asal-usul penamaan Desa Padarama.

Faktor yang memengaruhi penamaan Desa Sukaraja, yaitu faktor sosial. Hal tersebut dapat dilihat dari asal-usul penamaan desa tersebut. Diberikannya nama Sukaraja kepada desa tersebut karena raja atau pimpinan menyukai atau senang dengan warga Desa Sukaraja. Desa Sukaraja termasuk desa yang subur dan memiliki bermacam-macam tanaman palawija sehingga 
Deiksis: Jurnal Pendidikan Bahasa dan Sastra Indonesia, 7 (1) Januari 2020

DOI: $10.33603 /$ deiksis.v7i1.2219

(p-ISSN 2355-6633, e-ISSN 2548-5490)

ketika masyarakat mengajukan pemisahan desa selalu membawa hasil kebun ke pimpinan. Oleh karena itu, sebagai apresiasi kebaikan warga setempat akhirnya pimpinan atau Bupati memberikan izin kepada warga tersebut untuk memisahkan diri dari Desa Cihaur.

\section{Faktor Lingkungan Hidup}

Selain faktor sosial, dalam penamaan desa-desa di Kecamatan Ciawigebang, Kabupaten Kuningan juga ada faktor lingkungan hidup. Faktor tersebut berupa segala sesuatu yang berhubungan dengan alam. Adapun penamaan desa yang dipengaruhi oleh faktor lingkungan hidup sebagai berikut.

Desa Cihirup

Desa Ciomas

Desa Ciputat

Desa Lebaksiuh

Desa Kadurama

Desa Cihaur

Berdasarkan asal-usul penamaan desa, adanya nama Cihirup itu didasarkan pada sebuah sumur tua yang berada di desa setempat. Faktor lingkungan hidup tersebut menjadi salah satu alasan diberikannya nama Cihirup pada desa tersebut.

Faktor yang memengaruhi penamaan Desa Ciomas, yaitu faktor lingkungan hidup. Faktor tersebut didasarkan pada asal-usul penamaan Desa Ciomas. Nama Ciomas itu diambil dari sebuah sumber mata air yang mengeluarkan air berwarna seperti emas.

Faktor yang memengaruhi penamaan Desa Ciputat, yaitu faktor lingkungan hidup. Faktor tersebut ada karena nama ciputat diambil dari sebuah pohon yang dikenal dengan pohon Putat.

Faktor yang memengaruhi penamaan Desa Lebaksiuh, yaitu faktor lingkungan hidup. Hal tersebut didasarkan pada asal-usul penamaan desa tersebut. Nama lebaksiuh diambil dari sebuah pohon yang dikenal dengan pohon Siuh dan berada di lebak atau di bawah.

Faktor yang memengaruhi penamaan Desa Kadurama, yaitu faktor lingkungan hidup. Sebagai salah satu agar membedakan dari desa lainnya diambillah ciri khas dari desa tersebut, yaitu kadurama.

Faktor yang memengaruhi penamaan Desa Cihaur, yaitu faktor lingkungan hidup. Faktor tersebut didasarkan pada asal-usul penamaan Desa Cihaur.

\section{Faktor Sejarah}

Sejarah juga dalam penamaan desa menjadi faktor yang melatarbelakanginya. Adanya sejarah atau asal-usul dari tempat tersebut membuat masyarakat setempat memberikan nama sesuai sejarah pada masanya. Adapun penamaan desa yang dipengaruhi oleh faktor sejarah, yaitu sebagai berikut.

Desa Pangkalan

Desa Pajawanlor

Desa Ciawigebang

Faktor yang memengaruhi penamaan Desa Pangkalan itu faktor sejarah. Faktor tersebut didasarkan pada asal-usul dan makna dari Desa Pangkalan. 
Deiksis: Jurnal Pendidikan Bahasa dan Sastra Indonesia, 7 (1) Januari 2020

DOI: 10.33603/deiksis.v7i1.2219

(p-ISSN 2355-6633, e-ISSN 2548-5490)

Faktor yang memengaruhi penamaan Desa Sidaraja, yaitu faktor sejarah. Faktor tersebut didasarkan pada asal-usul penamaan desa tersebut.

Faktor yang memengaruhi penamaan Desa Pajawanlor, yaitu faktor asal-usul. Faktor tersebut didasarkan pada asal-usul penamaan Desa Pajawanlor. Desa yang mulanya merupakan bagian dari Desa Pajawan Kidul akhirnya dipisahkan menjadi Kampung Pajawanlor yang masuk ke Desa Ciputat dan memisahkan diri menjadi desa. Letak desa yang berada di sebelah utara Desa Pajawan Kidul merupakan faktor yang memengaruhi penamaan Desa Pajawanlor.

Faktor yang memengaruhi penamaan Desa Ciawigebang, yaitu faktor sejarah. Faktor tersebut didasarkan pada asal-usul penamaan desa tersebut. Nama yang diambil dari sebuah nama tempat yang disebut dengan kademangan dan sebbuah tokoh yang menaklukan wilayah tersebut Pangeran Sutajaya Gebang merupakan alasn diberikannya nama Ciawigebang pada desa tersebut.

\section{Faktor Letak}

Letak merupakan beradanya suatu tempat (KBBI V). Ada pula nama desa yang didasarkan pada letak atau sesuai dengan letak wilayah tersebut. Adapun penamaan desa yang dipengaruhi oleh faktor letak adalah sebagai berikut.

Desa Ciawilor

Desa Dukuhdalem

Desa Karamatmulya

Faktor yang memengaruhi penamaan Desa Ciawilor itu didasarkan pada letak desa yang berada di sebelah utara Desa Ciawigebang. Oleh karena itu, faktor yang memengaruhi penamaan tersebut adalah faktor letak.

Faktor yang memengaruhi penamaan Desa Dukuhdalem adalah faktor letak. Faktor tersebut didasarkan pada asal-usul yang pada masanya tempat tersebut merupakan tempat penyebaran agama oleh tokoh setempat. Pedukuhan tersebut berada di dalam sebuah hutan dan juga dijadikan sebagai tempat persembunyian warga dari para penjajah.

Faktor yang memengaruhi penamaan Desa Karamatmulya, yaitu faktor letak. Faktor tersebut sesuai dengan asal-usul penamaan Desa karamatmulya. Letak desa yang berada di sebuah tempat yang dikeramatkan dan harapan warga setempat agar desa tersebut memiliki mutu tinggi menjadi penyebab diberikannya nama karamatmulya pada desa tersebut.

\section{Faktor Geografi}

Geografi merupakan ilmu yang membahas mengenai permukaan bumi (KBBI V). Geografi merupakan faktor yang melatarbelakangi penamaan beberapa desa di Kecamatan Ciawigebang, Kabupaten Kuningan. Adapun penamaan desa yang dipengaruhi oleh faktor geografi ialah sebagai berikut.

Desa Cikubangmulya

Desa Cigarukgak

Desa Karangkamulyan

Desa Cikubangmulya merupakan hasil pemisahan dari Desa Cihirup. Nama cikubangmulya itu diambil dari keadaan geografi wilayah setempat, yaitu adanya sebuah 
Deiksis: Jurnal Pendidikan Bahasa dan Sastra Indonesia, 7 (1) Januari 2020

DOI: $10.33603 /$ deiksis.v7i1.2219

(p-ISSN 2355-6633, e-ISSN 2548-5490)

kubangan. Dengan demikian, faktor yang memengaruhi penamaan desa tersebut adalah faktor geografi.

Faktor yang memengaruhi penamaan Desa Cigarukgak adalah adanya sebuah keadaan jalan yang berlubang, rusak dan selalu digenangi air. Oleh karena itu akhirnya daerah itu disebut dengan Cigarukgak. Faktor geografi tersebut didasarkan pula pada makna yang terkandung dalam penamaan Desa Cigarukgak.

Faktor yang memengaruhi penamaan Desa Karangkamulyan itu diambil dari keadaan desa yang mulanya sebuah pekarangan luas. Adanya pekarangan yang kosong dan sebuah harapan yang menjadi latar belakang penamaan Desa Karangkamulyan. Dengan demikian, faktor yang memengaruhi penamaan desa tersebut adalah faktor geografi.

\section{Simpulan}

Berdasarkan hasil penelitian dan pembahasan di atas, dapat disimpulkan sebagai berikut.

Terdapat 24 desa yang berada di Kecamatan Ciawigebang. Adapun bentuk nama desa yang berada di Kecamatan Ciawigebang, yaitu Desa Ciawigebang, Ciawilor, Cihirup, Cihaur, Cigarukgak, Ciomas, Ciputat, Cijagamulya, Cikubangmulya, Karamatmulya, Dukuhdalem, Geresik, Lebaksiuh, Kadurama, Mekarjaya, Karangkamulyan, kapandayan, Pamijahan, Pangkalan, Padarama, Sidaraja, Sukadana, Sukaraja, dan Pajawanlor. Penamaan desa-desa di Kecamatan Ciawigebang merupakan bentuk komposisi atau gabungan dari dua sampai tiga kata. Selain itu, dalam penamaan desa juga menggunakan afiksasi atau penambahan imbuhan, seperti Desa Pamijahan, Karangkamulyan, dan Kapandayan.

Makna yang terkandung dalam penamaan desa-desa yang ada di Kecamatan Ciawigebang itu sangat beragam. Makna tersebut diambil dari asal kata setiap bentukan nama desa. Berdasarkan hasil pembahasan di atas, penamaan desa itu memiliki makna yang berhubungan dengan pimpinan, harapan masyarakat setempat, kebiasaan penduduk, letak, keadaan lingkungan hidup yang dikeramatkan, dan sejarah yang ada di desa setempat.

Faktor yang memengaruhi penamaan desa-desa di Kecamatan Ciawigebang, di antaranya karena faktor sosial, lingkungan hidup, sejarah, letak dan geografis. Faktor-faktor tersebut sesuai dengan sejarah atau asal-usul penamaan desa.

\section{Saran}

Adapun saran yang dapat diambil dari penelitian ini, yaitu:

1. Bagi peneliti, penelitian mengenai toponimi atau asal-usul desa di Kecamatan Ciawigebang masih sangat sederhana. Masih memerlukan penelitian yang lebih lanjut, seperti yang sudah disampaikan dalam implikasi.

2. Bagi pembaca atau masyarakat, hendaknya memiliki rasa kepedulian terhadap peninggalan sejarah, seperti cerita rakyat dan situs peninggalan zaman dahulu.

3. Bagi guru, asal-usul penamaan tempat atau sejarah desa dapat digunakan sebagai media untuk mengenalkan kebudayaan atau kearifan lokal setempat.

4. Bagi pemerintah, hendaknya pemerintah menjadi wadah untuk memfasilitasi produkproduk budaya setempat. 
Deiksis: Jurnal Pendidikan Bahasa dan Sastra Indonesia, 7 (1) Januari 2020

DOI: 10.33603/deiksis.v7i1.2219

(p-ISSN 2355-6633, e-ISSN 2548-5490)

\section{Daftar Pustaka}

Aminuddin. (2016). Semantik Pengantar Studi tentang Makna. bandung: Sinar Baru Algensindo.

Asadi. (2015). Nama Rupabumi, Toponim, Aturan dan Kenyataan. Jurnal Lingkar Widyaiswara, 2(4), 18-35. Diunduh dari http://juliwi.com/published/E0204/Juliwi0204_18-35.pdf

Aslinda, \& Syafyahya, L. (2014). Pengantar Sosiolinguistik. (A. Susana, Ed.). Bandung: PT Refika Aditama.

Camalia, M. (2015). Toponimi Kabupaten Lamongan (Kajian Antropologi Linguistik). Parole, 5(1), 74-83. Diunduh dari https://ejournal.undip.ac.id

Chaer, A. (2008). Morfologi Bahasa Indonesia (Pendekatan Proses). Jakarta: Rineka Cipta.

Chaer, A., \& Agustina, L. (2014). Sosiolinguistik: Perkenalan Awal (Revisi). Jakarta: Rineka Cipta.

Endraswara, S. (2013). Folklor Nusantara: Hakikat, Bentuk, dan Fungsi. Yogyakarta: Ombak.

Istiana. (2012). Bentuk dan Makna Nama-nama Kampung Di Kecamatan Kotagede. Program Studi Bahasa Dan Sastra Indonesia Fakultas Bahasa Dan Seni Universitas Negeri Yogyakarta. Yogyakarta. Diunduh dari https://eprints.uny.ac.id

Komariah, Y. (2018). Pengembangan Bahan Ajar Cerita Rakyat Kuningan Terintegrasi Nilai Karakter dalam Pembelajaran Apresiasi Sastra di SMP. Pendidikan Bahasa Dan Sastra Indonesia, 5(1), 100-110. Retrieved from https://jurnal.unswagati.ac.id/index.php/Deiksis

Kurniasih, D., \& Zuhriyah, siti A. (2017). Alih Kode dan campur Kode di Pondok Pesantren Mahasiswa Darussalam. Indonesian Language Education and Literature, 3(1), 53-65. Diunduh dari http://www.syekhnurjati.ac.id/jurnal/index.php/jeill/

Mulyaningsih, I., \& Itaristanti. (2018). Pembelajaran Bermuatan HOTS (Higher Order Thinking Skill) di Jurusan Tadris Bahasa Indonesia. Indonesian Language Education and Literature, 4(1), 114 128. http://doi.org/10.24235/ileal.v4i1.2970

Parera, J. D. (2004). Teori Semantik. (I. Syafrida \& Y. Sumiharti, Eds.) (Kedua). Jakarta: Erlangga.

Pianto, H. A. (2016). Pentingnya Penulisan Sejarah Lokal Di Pacitan Tahun 1999-2014. Sosiohumaniora, 2(2), 92-100. http://doi.org/http://dx.doi.org/10.30738/sosio.v2i2.553

Purwanto, A. (2010). Analisis Isi dan Fungsi Cerita Prosa Rakyat di kanagarian Kota Besar, Kab Dharmasraya. Ilmu Sosial Dan Humaniora2, 1(2), 155-164. Diunduh dari https://wacanaetnik.fib.unand.ac.id

Ramlan, M. (2005). Ilmu Bahasa Indonesia: Sintaksis (kesembilan). Yogyakarta: Karyono.

Romadi, \& dkk. (2010). Penelusuran Arsip dan Sumber Lisan dalam Rangka menyusun Sejarah Desa bagi Perangkat Desa dan Anggota BPD Desa Bocor Kecamatan Buluspesntren Kab. Kebumen. Abdimas, 14(1), 1-6. Diunduh dari https://journal.unnes.ac.id/nju/index.php/abdimas/article/view/17

Ruspandi, J., \& Mulyadi, A. (2014). Fenomena Geografis Di Balik Makna Toponimi Di Kota Cirebon. Jurnal Gea, 14(23), 1-13. Diunduh dari https//:download.poortalgaruda.org

Sugiyono. (2014). Metode Penelitian Kuantitatif, Kualitatif, dan R\&D. Bandung: Alfabeta.

Sukmana, E. (2018). Aspek Sosial Budaya dalam Cerita Enyeng di Desa Cipancar. Pendidikan Bahasa

Dan Sastra Indonesia, 5(1), 18-23. Diunduh dari http://jurnal.unswagati.ac.id/index.php/Deiksis Sumarsono. (2017). Sosiolinguistik. Yogyakarta: SABDA.

Sunandar, A. (2018). Kamus Bahasa Sunda - Indonesia, Indonesia - Sunda, Sunda - Sunda (4th ed.). Jakarta: PT Buku Pintar Indonesia.

Sutriati, N., WS, H., \& Zulfadhli. (2012). Kategori dan Fungsi Sosial Cerita Rakyat di Kenegerian Kari Kecamatan Kuantan Tengah Kabupaten Kuantan Singingi Provinsi Riau. Pendidikan Bahasa Dan Sastra Indonesia, 1(1), 126-131. Diunduh dari ejournal.unp.ac.id/index.php/pbs/article/view/236 
Deiksis: Jurnal Pendidikan Bahasa dan Sastra Indonesia, 7 (1) Januari 2020

DOI: 10.33603/deiksis.v7i1.2219

(p-ISSN 2355-6633, e-ISSN 2548-5490)

Tarigan, H. G. (2009). Pengantar Semantik. Bandung: Angkasa. 